\title{
Psychosemantic Reconstruction of Health Concepts in Patients with Somatogenia
}

\section{Психосемантична реконструкція уявлень про здоров'я у пацієнтів із соматогенією}

\author{
Ksenia Maksymenko \\ Dr. in Psychology, \\ Professor
}

\author{
Ксенія Максименко \\ доктор психологічних наук, \\ професор
}

E-mail: ksenia.maximenko@,gmail.com orcid.org/0000-0002-6102-2479

\section{Olena Kudermina}

Dr. in Psychology,

Associate Professor,

Head of the Department

of Legal Psychology

\section{Олена Кудерміна}

доктор психологічних наук, доцент,

завідувач кафедри

юридичної психології

\section{E-mail: alenakudermina@gmail.com orcid.org/0000-0002-4959-7413}

National Academy

of the Internal Affairs of Ukraine

$\triangle 1$, Solomyanska Str., Kyiv,

Ukraine, 02000
Національна академія внутрішніх справ України

$\triangle$ вул. Солом'янська площа, 1 , м. Київ, Україна, 02000

Original manuscript received September 15, 2018

Revised manuscript accepted February 25, 2019

\section{ABSTRACT}

The article presents the results of study of the subjective psychosemantic space of patients suffering from somatogeny. The construction of a subjective semantic space is fundamentally different from the descriptive researches because it involves an experiment that simulates the certain aspects of linguistic or cognitive activity 
and allows the reconstruction of the system of values. This is a study of the psychosemantic structure of those semantic structures of consciousness that create a typical conceptual system of self-regulation, forming a normative and actual subjective picture of the own ideas about the health and psychological causes of its violation.

On the example of patients with chronic gastroenterological and cardiovascular diseases, the author used the method of semantic differential by Ch. Ozgud with the subsequent factorization of data and has established the basic psycho-semantic parameters of such patients' consciousness, which allows to understand how people with a certain structure of consciousness fall into the number of patients suffering from psychogeny. The semantic differential method allows us to evaluate the subjective aspect of the meanings associated with content, social settings, stereotypes and other emotionally loaded, structured, and not enough apperceived forms of generalization. The study was conducted in three stages. At the first one was used the adoption of associations. At the second stage was obtained an array of data that represented the result of applying the semantic differential method to the description of the specified categories. The third stage was aimed at working out the received factual data.

Through the study, there were obtained the results as three factors. The main factor was called "Score». The second (partial) bipolar factor absorbed three scales and received the name - antonym to the classical scale of Ch. Osgood "Weakness». The third (partial) unipolar factor also contains three scales. It received the name "Activity».

The study revealed a number of common features that characterize the partial psychosemantic space of such patients. It was found that the psychosemantic parameters of the psychosemantic space of patients differ by its cognitivelyemotional simplicity, low dimensionality, inconsistency and predominance in negative connotations.

The psychosemantic structure of consciousness of the patients suffering from psychogeny involves the special efforts of clinical psychologists and psychotherapists in providing targeted psychological support and assistance to such people.

Key words: structure of consciousness, psychosemantic space, somatogeny, factor analysis, psychological help.

\section{Вступ}

Сучасний розвиток психолінгвістики ознаменований бурхливим розвитком саме прикладної психолінгвістики, проникненням іiі у різні соціальні сфери буття людини. Ї̈і методи все більше стають затребуваними в дослідженнях із психотерапії, психоконсультування, клінічної психології тощо. Не винятком стала і медична психологія, зокрема проблема соматогеній i психологічних механізмів їх породження, яка привертає все більшу увагу дослідників 
(Гончаров, 2011; Коростий, 2011a, 2011b; Кудінова, 2011; Маркова \& Кутова, 2015; Максименко, 2015; Максименко \& Калмиков, 2018; Максименко \& Орап, 2018; Мелзак, 1981; Михайлов, Романова, Андрух та ін., 2011; Петренко, 2005; Прохоров, 2004; Штрахова, 2009; Pagoto, 2011; Pervichko, Zinchenko \& Pak, 2016; Tuval-Mashiach, Freedman, Bargai et al., 2004 та ін.). Сам цей факт, на нашу думку, зумовлений двома основними психолінгвістичними (смисловими й семантичними) тенденціями. По-перше, незважаючи на факт активної розробки препаратів, які дійсно дозволяють позбутися хронічних захворювань, скажімо в галузі гастроентерології та кардіології, рівень захворюваності в усьому світі не спадає, а, навпаки, зростає, ще раз підтверджує добре відому аксіому: лікувати слід не хворобу, а індивідуальні смисли хворого. Й, відповідно до думки сучасних дослідників, саме психологічні фактори мовленнєвого впливу займають важливе місце в етіопатогенезі цієї категорії захворювань. По-друге, з'являється все більше емпіричних досліджень, 3 яких випливає, що якраз особистісно-смислові чинники й виступають однією 3 передумов руйнування здоров'я, слугуючи, як це не прикро, своєрідним тригером, що відкриває шляхи патологічним соматичним процесам у людському організмі. Ці міркування й зумовили постановку проблеми даного дослідження. Справа ще й в тому, що на тлі процесів «демедикалізації» соматичних симптомів, що полягають у пошуку хворими метасмислів хвороби (містичних, парарелігійних, панпсихологічних тощо), руйнується здорова картина того, що відбувається, не створюється адекватна ситуації система життєтвірних смислів. Все це й диктує необхідність за допомогою психолінгвістичних методів, зокрема психосемантичної реконструкції визначати головні параметри смислового орієнтування особистості в системі власних смислів щодо життєвої ситуації, ускладненої соматогенією. Зрозуміло, що різні патологічні стани створюють, індукують і різну внутрішню картину хвороби. Але, як показує практика, серед зазначених численних досліджень виникла своєрідна психологічна лакуна, яка стосується не стільки вивчення внутрішньої картини хвороби, скільки розуміння людьми, що постраждали внаслідок соматогеній, визначальної психологічної структури їхніх уявлень про здоров'я. Йдеться про те, що дослідники віддають перевагу традиційним опитувальникам при встановленні внутрішньої картини хвороби, оминаючи вельми 
ефективні й доречні якраз у цих випадках психолінгвістичні, й зокрема психосемантичні методи досліджень. Іншими словами, саме дослідження суб'єктивного образу захворювання, що розкриває систему смислових структур свідомості, зостається поза межами традиційних дослідження, хоча саме психосемантична реконструкція системи категоризацій психологічної реальності особистості відкриває можливості для утворення типових концептуальних систем саморегуляції, формуючи нормативну та фактичну суб'єктивну картину уявлень пацієнта про здоров'я та психологічні причини й наслідки його порушення. Побудова суб'єктивного семантичного простору принципово відрізняється від описових досліджень тим, що передбачають проведення експерименту, який моделює ті чи інші аспекти мовної або когнітивної картини світу й дозволяє здійснити реконструкцією системи значень. Особливого сенсу це набуває в дослідженнях мовної свідомості людей, які страждають на соматогенію, оскільки, на відміну від психогенії, соматогенія виступає як суто індивідуалізований значеннєво-смисловий спосіб реагування індивіда на власні проблеми 3 соматичним здоров'ям. Отже, психолінгвістичні й психосемантичні підходи відкривають шлях до простору значень і смислів, якими керується особистість. Воднораз вони вводять фахівця (лікаря, психолога, психотерапевта) у життєвий світ «мовної особистості», відкриваючи суб'єктивний світ людини у іiі власній системі смислових і мовних координат.

На перший погляд, розвідок, спрямованих на вивчення соматогенію 3 метою подальшої розробки алгоритму психотерапевтичної допомоги, досить багато (Гончаров, 2011; Леонтьев, 2007; Максименко, 2014; Максименко \& Орап, 2018; Мелзак, 1981; Петренко, 2005; Прохоров, 2004; Щеглов, 2006; Штрахова, 2009; Kreitler, S. \& Kreitler, H., 1985; Pervichko, Zinchenko \& Pak, 2016 та ін.). Зокрема, з'ясовано, що агресивне середовище, хронічні страхи і конфліктні стани провокують у пацієтів, скажімо, 3 гастронетеролгічними захвроюваннями образливість, підозрілість, ворожість до оточуючим (Гончаров, 2011; Коростий, 2011a, 2011b; Максименко, 2014; Максименко \& Калмиков, 2018), в той час як пацієнти 3 хронічними серцевосудинними захворюваннями відзначаються підвищеною тривожністю, страхами, нав'язливостями тощо (Кудінова, 2011; Мелзак, 1981; Михайлов, Романова, Андрух та ін., 2011; Щеглов, 
2006; Петренко, 2005; Прохоров, 2004). Проте, насправді неважко переконатися в тому, що дослідники віддають перевагу традиційним опитувальникам при встановленні внутрішньої картини хвороби, оминаючи вельми ефективні й доречні якраз у цих випадках психолінгвістичні й зокрема психосемантичні методи дослідждення. $€$ лише нечисленні розвідки як вітчизняних, так і зарубіжних учених, в яких застосовуються такі методи (Максименко, 2015; Петренко, 2005; Pervichko, Zinchenko \& Pak, 2016). Ці роботи, як вітчизняних, так і зарубіжних фахівців, справедливо фокусуються на перцептивних, смислових, вербальних маркерах страждань, але їхній спектр охоплюваної феноменології досить вузький. Він стосується переважно двох компонентів страждання: тривоги й болю. Більш широке охоплення проблематики, скажімо, стосовно соматогенії як окремої феноменології дослідниками не здійснюються. На наш погляд, це пов'язане з особливою складністю таких наукових розвідок. Адже психологи до цих пір недостатньо задіяні у сфері клінічної психології, віддаючи перевагу практичній психології, а лікарі не володіють методологією та методиками психосемантичних досліджень, які, як відомо, передбачають застосування асоціативного експерименту, суб〉єктивного шкалювання, семантичного диференціалу. При цьому головний етап дослідницької процедури вимагає застосування методів багатомірної статистики, що дозволяють виокремити імпліцитну систему значень, властивих даному суб'єкту чи даній групі (Артемьева \& Мартынов, 1975; Леонтьев, 2007; Петренко, 2005; The Emotional Impact..., 2012; Pervichko, Zinchenko \& Pak, 2016).

Meта статті полягає у висвітленні ментальних аспектів впливу хвороби на особистісне «Я», що відкриває, на наш погляд, магістральний шлях до прогнозування й подолання наслідків впливу соматики на психічні стани пацієнта з урахуванням індивідуальнопсихологічних i особистісних чинників, зокрема зважаючи на внутрішні й зовнішні ресурси, які відіграють стимулюючу або гальмуючу роль у подоланні труднощів, викликаних хворобою. Методологія i психотехніка психосемантичної реконструкції особистісного «Я» в клініці захворювань різного спектру не може не спиратися на розуміння особливостей когнітивного, емотивного, поведінкового компонентів системи ставлень до хвороби; на знання психології здоров'я і особливостей особистісних ресурсів людини, 
що страждає захворюванням; на розуміння співвідношення клінічних, психофізіологічних, психологічних механізмів особистісних розладів при виборі відповідних психолінгвістичних технік, вербальних втручань й особистісно-орієнованої і симптоматичної психотерапії. Всі ці обставини й міркування зумовили постановку головної мети нашого дослідження: реконструкцію методами психосемантики уявлень пацієнтів з соматогеніями про здоров’я.

\section{Методи і методики дослідження}

Процееура дослідження: група пацієнтів-респондентів містила в загальній сукупності 39 осіб (14 чоловіків і 25 жінок) у віці від 23 до 62 років 3 діагнозами: серцева недостатність $(\mathrm{CH}) 2-3$ ступеня i хронічний холіцестит $(\mathrm{XX})$ в стадії загострення. При цьому 9 жінок і 5 чоловіків проходили повторну госпіталізацію. В якості контрольної групи для порівняння результатів 3 умовною нормою була набрана група добровольців зі студентів факультету медичної психології НМУ ім. О.О. Богомольця в кількості 27 чол. Основним експериментальним методом слугував семирядний семантичний диференціал Ч. Осгуда (в адаптації В.Ф. Петренка, 2005), що включає 18 біполярних шкал за трьома основними категоріями: активність, валентність, та потентність (сила), протилежні полюси яких задані за допомогою антонімів. Заснований на уніфікованій системі координат семантичний диференціал в діагностичному плані виявляється найбільш пристосованим для вимірювання середньостатистичних оцінних реакцій на об'єкт, властивих певній масовій групі респондентів. Метод семантичного диференціалу це техніка, яка базується на застосуванні факторного аналізу, щоб дослідити значення певних явищ та понять для людини. На думку авторів методики, фактор, який налічує сукупність шкал, є змістовим інваріантом, в якому поєдналися знання про об’єкт та відношення до нього. Саме тому метод семантичного диференціалу дозволяє оцінити суб'єктивний аспект значень, які пов'язані зі змістом, соціальними установками, стереотипами та іншими емоційно навантаженими, структурованими i малоусвідомленими формами узагальнення. Основним психолінгвістичним методом досліджень

3 експериментальної психосемантики $є$ побудова семантичних 
просторів - своєрідне моделювання категоріальних структур індивідуальної мовної свідомості. Завданням психосемантики $є$ вивчення загальнопсихологічних і специфічних аспектів процесу утворення категорій у свідомості людини. Психосемантичний підхід дає можливість поглянути на світ «очима досліджуваного», відчути те, як саме він сприймає оточуючих і навколишнє середовище. Даний підхід реалізує парадигму «суб'єктного» підходу до розуміння іншої людини (Артемьева \& Мартынов, 1975; Михальский, Иванов, Максютин \& Моргенштерн, 1996). Оскільки оцінювання понять, явищ є завжди процесом суб'єктивним і базується на конотативному значенні об'єкту, який оцінюється, тобто на особистісному смислі, то експериментальна психосемантика $є$ чудовим інструментом для дослідження оцінного компоненту мовної свідомості. В.Ф. Петренко вважає, що конотативне значення $\epsilon$ найближчим до поняття суб'єктивного змісту свідомості людини, під яким розуміють ставлення суб'єкта до світу у формі значень (Петренко, 2005). Мова йде про особистісні конструкти, які й визначають категоріальне структурування дійсності у формі емоційного забарвлення об'єкта чи явища, а також у формі неусвідомлених установок. Побудова суб'єктивного семантичного простору допомагає зрозуміти, як саме індивід здійснює аналіз будь-якого соціального феномена, а також вирішує проблему дослідження глибинних структур психіки людини, що відповідають за регуляцію поведінки людини стосовно і соціуму, і самої себе. Оскільки метод семантичного диференціалу передбачає застосування факторного аналізу та математичностатистичного аналізу, то варто зазначити, що цей, до певної міри, класичний метод можна було б і модифікувати, запропонувавши додаткові біполярні шкали, якби наше дослідження носило б менш прикладний характер, і ми працювали б зі здоровими людьми, наприклад, 3 таким традиційним контингентом для досліджень 3 загальної психології як студенти. Тоді це мало б рацію. Але нашими інформантами були пацієнти - люди, які потерпають від страждань (лат. - patiens - від «pati» - страждати, потерпати). Тому ми не вважали припустимим перевантажувати їх додатковим напруженням, хоча у перспективі маємо намір продовжувати дослідження, застосовуючи додаткові, більш диференційовані шкали. 


\section{Результати дослідження}

Дослідження проходило у три етапі. На першому етапі пацієнтам пропонувалося записати слова, що асоціюються в них 3 поняттям «здоров'я». Далі досліджуваним було запропоновано доповнити список слів-стимулів, пов'язаних з цим поняттям. Всього було отримано 49 слів-асоціацій від 39 піддослідних. Зрозуміло, що при цьому певні відповіді-асоціації через довільність та спрацьовування захисних механізмів виявилися малозначущими, але в процесі подальшого опрацювання результатів були виокремлені найбільш частотні поняття-категорії: «самопочуття», «дисциплінованість», «усвідомлення», «радість», «благополуччя», «свобода». На другому етапі було отримано масив даних, що представляли собою результат застосування методики семантичного диференціалу до опису зазначених категорій і який набув вигляду матриці розміром $39 \times 6 \times 18.3$ метою виявлення характеристик, за якими пацієнти описують категорії ставлення до поняття «здоров'я», матрицю було факторизовано за методом головних компонент, який дозволяє забезпечити максимальну інформативність одержаних даних.

У дослідженні ми виходили з гіпотези про те, що соматична хвороба не тільки сприяє виникненню певних, специфічних станів, a й, головне, викликає інші форми їх переживань. При цьому нас цікавили не окремі захворювання та їхня специфіка, а більш загальні тенденції, що властиві, як ми і припускали, будь-якому стану, пов'язаному з соматичною хворобою. Ці вихідні міркування зумовили специфіку побудови й розгортання експериментальної ситуації і вибір досліджуваних. У процедурному плані експеримент являв собою три послідовні етапи індивідуальної діагностичної роботи з обстежуваними.

На першому етапі дослідження у процесі психологічного інтерв'ю з'ясовувалося, який саме психічний стан наразі у досліджуваного. Важливо відзначити, що насправді процедура інтерв'ю формувала переживання актуального стану. Таким чином, зміст цього етапу полягав не стільки в діагностуванні, скільки в специфічному відрефлексуванні переживання стану, в результаті чого останнє не тільки усвідомлювалося суб'єктом, але й 
представлялося у вигляді певної семантеми (назви). За результатами цього етапу було встановлено, що при проведенні дослідження індивіди переживали такі психічні стани: напруження - 9 осіб; тривога - 8 осіб; страх - 4 особи; невизначеність - 3 особи; туга 3 особи; сум - 3 особи; самотність - 2 особи;апатія - 2 особи; байдужість - 2 особи; пригніченість - 1 особа; нестабільність 1 особа; задоволення - 1 особа.

3 переліченого зрозуміло, що у хворих спостерігалося абсолютне переживання негативних (астенічних) станів (за винятком одного пацієнта): лише одна особа переживала стан задоволення). Для порівняння наведемо результати контрольної групи: тривога 7 осіб, радість - 6 осіб, туга - 4 особи, пригніченість - 3 особи, напруження - 2 особи, втома - 2 особи, збудження - 1 особа, розчарування - 1 особа, задоволення - 1 особа. Всього $30 \%$ осіб переживали стенічні стани (радість, задоволення).

Можливо, варто допустити, що переживання астенічних станів $\epsilon$ характерною ознакою соматичного захворювання. Для нашого дослідження важливо те, що пацієнти 3 соматичним діагнозом дають більше різних назв станам, що ними переживаються. Мабуть, варто уточнити, що в нашій вибірці діагнози розподіляються таким чином: гіпертонічна хвороба 2 ступеня - 9 осіб, виразкова хвороба шлунку - 7 осіб, пієлонефрит - 2 особи, IXC -8 осіб, ішемічний інсульт - 1 особа, виразка 12-палої кишки - 1 особа, гостра пневмонія - 1 особа, бронхіт в стадії загострення - 1 особа, хронічна ниркова недостатність 2 ступеня - 1 особа, хронічна серцева недостатність - 5 осіб, цироз печінки - 3 особи.

Отримані нами дані узагальнено у нижче наведеній таблиці 1.

3 таблиці 1 видно, що переживання психічних станів, принаймні в нашій вибірці, не має специфічної прив'язки до конкретного соматичного захворювання.

На першому етапі нашого емпіричного дослідження було встановлено таке: пацієнти 3 соматичним діагнозом переживають здебільшого психічні стани за астенічним типом; емоційні стани, що супроводжують соматичне захворювання, не мають прямого стосунку до конкретного діагнозу, і в цьому розумінні можуть вважатися неспецифічними; пацієнти 3 соматичним діагнозом схильні більш уважно ставитися до власних емоційних станів, більш чітко їх диференціюючи, що може свідчити про більшу 
значущість для них власне емоційних забарвлень страждання, ніж самої соматичної хвороби.

Таблиця 1. Співвідношення психічних станів і соматичних захворювань

\begin{tabular}{|c|c|c|c|c|c|c|c|c|c|c|}
\hline \multirow[t]{2}{*}{ Захворювання } & \multicolumn{10}{|c|}{ Стан } \\
\hline & 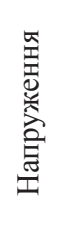 &  & 岂 & 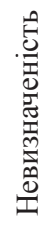 & $\stackrel{\pi}{E}$ & $\sum_{j}^{\vdots}$ & 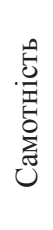 & 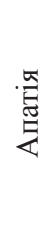 & 疍 & 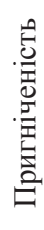 \\
\hline Ішемія & + & & & & & & & & & \\
\hline Гіпертонія & & & & + & & & & & & \\
\hline Інсульт & & & & & & & & & & + \\
\hline Пієлонефрит & & + & & & & & & & & \\
\hline Виразка шлунку & & + & & & & & & + & & \\
\hline Пневмонія & & + & & & & & & & & \\
\hline Виразка 12-палої кишки & & & & & + & & & & + & \\
\hline Гіпертонія & + & & & & & + & & & & \\
\hline Бронхіт & + & & & & & & & & & \\
\hline Гастрит & & + & + & & & + & & & & \\
\hline Гіпертонія & + & & & & & & & & & \\
\hline Хронічна ниркова недостатність & & & + & & & & & & & \\
\hline Хронічний холецистит & & & & + & & & & & & \\
\hline Серцева недостатність & & & & & & & & & + & \\
\hline Нефрит & & & & & + & & & & + & \\
\hline
\end{tabular}

3’ясуванню детермінант вказаної феноменології був присвячений другий етап роботи. Дослідження проводилося 3 експериментальною $(n=39)$ i контрольною $(n=27)$ групами відразу ж після першого етапу. 3 кожним досліджуваним проводилася індивідуальна робота. В ході цієї роботи піддослідним пропонувалося оцінити свій стан за опитувальником «Рельєф психічного стану», розробленим А.О. Прохоровим (Прохоров, 2004). Опитувальник містить шкали психічних процесів, фізіологічних реакцій, переживань i поведінки. В інструкції пропонувалося по 11-бальній шкалі оцінити свій поточний стан (його ми досліджували на першому етапі) i, по можливості, «увійти в нього». Важливо зазначити, що цей опитувальник розроблено відповідно 
до концепції «нерівноважних станів», що зафіксовано у поданні й інтерпретації результатів: припускається, що показники в межах $5 \pm 0,5$ балів свідчать про «рівноважний» (власне, здоровий) характер перебігу станів. Відхилення від цієї числової галузі свідчать про тенденцію до патологізації (агравації) станів, про їх зміщення до загострення та реактивності (високі показники) або, навпаки, до пригнічення та поглинання із втратою чутливості та гнучкості (низькі показники) цих станів.

У результаті факторизації було отримано три значущих фактори, як видно з таблиці 2. При цьому перший (головний) фактор охоплював 27,3\% дисперсії, другий та третій відповідно $11,2 \%$ та 10,2\% дисперсії.

Навантаження шкал по кожному факторові подано в таблиці 2.

Таблиця 2. Факторні ваги шкал оберненої матриці

RotatedComponentMatrix*

\begin{tabular}{lccccc}
\hline \multicolumn{5}{c}{ Component } \\
\hline gorjkoe & 1 & 2 & 3 & 4 & 5 \\
pelalnoe &,- 816 &,- 015 &,- 015 &, 046 &,- 015 \\
prijatnoe &,- 771 &,- 017 &,- 045 &, 070 &,- 038 \\
horowee &, 733 &, 078 &, 224 &, 147 & -.013 \\
tiazholoe &, 694 &, 277 &, 205 &,- 098 &, 196 \\
nezhnoe &,- 677 &, 234 &,- 133 &, 143 &,- 045 \\
holodnoe &, 640 &,- 194 &, 168 & -.125 &, 190 \\
krasivoe &,- 614 &,- 020 &,- 017 &, 137 &, 229 \\
mjagkoe &, 613 &, 172 &, 248 &,- 129 &, 323 \\
grjaznoe &, 599 &, 116 &, 380 &,- 076 &,- 043 \\
silnoe &,- 592 &,- 042 &,- 312 &, 241 &,- 102 \\
glybokoe &,- 023 &, 820 &, 072 &, 012 &, 042 \\
malenkoe &, 050 &, 708 &, 071 &, 173 &, 189 \\
spokojnoe &, 003 &,- 580 &, 065 &, 471 &, 352 \\
bod roe &, 175 &,- 073 &, 869 &, 119 &, 078 \\
aktivnoe &, 348 &, 210 &, 620 &,- 182 &,- 082 \\
medlennoe &, 184 &, 395 &, 472 &,- 457 &, 120 \\
ostroe & -.241 &, 205 &,- 021 &, 789 &,- 146 \\
\hline Extraction &, 073 &, 131 &, 009 &,- 106 &, 859 \\
\hline
\end{tabular}

Extraction Method: Principal Component Analysis. Rotation Method:

Varimax with Kaiser Normalization, a. Rotation converged in 8 iterations. 
Як видно з наведених даних, незважаючи на загалом незначну кількість факторів, кожен з них виявився досить сильним, що, звісно потребує окремих пояснень з урахуванням як кількості вимірюваних понять і ознак, так і кількості піддослідних. Зокрема, відразу можна зазначити, що йдеться про побудову часткового семантичного простору стосовно уявлень про таку екзистенційну цінність як здоров'я. Перелічимо зокрема найменування та навантаження по головному факторові: гірке - солодке $(0,82)$; сумне - радісне $(0,77)$; приємне - відразливе $(0,73)$; гарне - погане $(0,69)$; важке - легке $(0,68)$; ніжне - суворе $(0,64)$; холодне - гаряче $(0,61)$; красиве потворне $(0,61) ;$ м'яке - тверде $(0,60)$; брудне - чисте $(0,59)$.

Головний фактор отримав назву «Оцінка». Зрозуміло, що цей біполярний фактор втілює емоційне ставлення до оцінюваної категорії, виражаючи собою прийняття або неприйняття емоційної цінності,що розглядається й описується. Важливим видається обставина, що шкал, які увійшли до головного фактору, описують категорії ставлення у ессенціальному та функціональному аспектах. Іншими словами, у свідомості пацієнтів,що страждають на соматогенію, якість життя та стан, що кваліфікується як «здоров'я» можуть бути «м'якими», «приємними», «добрими», «ніжними», «красивими» i, в той же час, «гіркими», «сумними», «важкими», «холодними», «брудними». Звичайно ж, тут йдеться про суб’єктивні характеристики, але важливою $є$ та обставина, що зазначена категорія не описується як безумовно позитивна, що, на нашу думку, розкриває потаємні стосунки особистості пацієнта з власним життям та власними стратегіями його проживання. Але повернемося до подальшого ознайомлення з отриманими даними.

Другий (частковий) біполярний фактор увібрав в себе три шкали і отримав назву «антонім» до класичної шкали Ч. Осгуда «Слабкість»: сильне - слабке $(0,82)$; глибоке - мілке $(0,71)$; маленьке - велике $(0,58)$. Хоча даний частковий фактор є слабким, він відверто свідчить про те, що за своєю структурою категорія «здоров'я» для пацієнтів, що страждають на соматогенію, $\epsilon$ воднораз і дійсно впливовою, і в той же час вразливою, і непевною екзистенційною категорією. Неважко за цим фактором помітити страхи, побоювання та власну вразливість людини: невпевненість у своєму здоров’ї, зневіру в його стійкості і силі. Чи не може 
ця обставина бути однією 3 психологічних причин виникнення соматогеній? Чи не свідчить цей факт про величезну залежність самопочуття людини від структури й змісту тієї психосемантики, у простір якої вона занурена?

Третій (частковий) уніполярний фактор також містить три шкали. Він отримав назву «Активність»: спокійне - бурхливе (0,87); бадьоре - мляве $(0,62)$; активне - пасивне $(0,47)$. Як легко бачити, даний фактор поєднує характеристики, 3 одного боку, безумовно, атрибутивні, а з іншого - позначені якостями пасивності та млявості, що при слабкій насиченості фактора красномовно засвідчує про розчарування та недовіру піддослідних (реципієнтів) до власного здоров'я. Заслуговує на увагу однополярність фактору. За існування у свідомості пацієнта беззаперечно нормативно позитивного ставлення до здоров'я, яке, як ми розуміємо, підсвідомо декларується самому собі, вони підсвідомо, але послідовно зберігають у своєму психосемантичному просторі тіньові аспекти оцінюваної екзистенційної категорії, що зайвий раз вказує на причини виникнення соматогеній у певної категорії людей. Останнє положення знайде відображення у висновках.

Як відомо, побудова суб'єктивного семантичного простору становить собою спробу визначення операційної моделі категоризації людиною дійсності, що не просто описує внутрішній світ людини, a й спосіб його конструювання. Семантичний простір пацієнтів, що страждають на соматогенії, налічує шість екзистенційних категорій: три категорії саморегуляції: «самопочуття», «дисциплінованість», «усвідомлення» та три категорії психічного стану: «радість», «благополуччя», «свобода». Розташування даних понять в семантичному просторі зумовлене оцінками пацієнтів за кожним фактором. Підрахувавши спочатку суму всіх оцінок за шкалами, що входять до кожного фактору та обчисливши середнє арифметичне значення оцінок для кожного поняття («самопочуття», «дисциплінованість», «усвідомлення», «радість», «благополуччя», «свобода»), ми отримали загальну картину середніх значень оцінок для кожного поняття (табл. 3).

Як видно з таблиці 3, у семантичному просторі розташовано шість категорій пацієнтів, що страждають на соматогенію, з їхніми оцінками по кожному фактору. Аналіз цих оцінок демонструє певну полярність уявлень пацієнтів про категорії саморегуляції. 
Респонденти позитивно оцінили всі зазначені поняття за фактором «Оцінка» (Ф1). Характерно, що найвищі показники за фактором «Оцінка» (Ф1) відзначаються стосовно понять «самопочуття» $(0,9)$ та «свобода» $(0,9)$. Вказані категорії, очевидно, пов'язані 3 глибокими переживаннями респондентів, оскільки екзистенціал «свобода» належить до того ж самого фактору, що й категорія «самопочуття». Їх одночасно висока вага безперечно вказує на граничну смислову важливість вказаних понять для саморозуміння та процесів саморегуляції пацієнтів з соматогенією.

Таблиця 3. Середні оцінки для кожного поняття за факторами

\begin{tabular}{lccc}
\hline & $\begin{array}{c}\boldsymbol{\Phi} 1 \\
\text { «Оцінка» }\end{array}$ & $\begin{array}{c}\mathbf{\Phi 2} \\
\text { «Слабкість» }\end{array}$ & $\begin{array}{c}\text { Ф3 } \\
\text { «Активність» }\end{array}$ \\
\hline Самопочуття & 0,9 & 0,7 & $-0,2$ \\
Дисциплінованість & 0,4 & $-0,29$ & $-0,4$ \\
Усвідомлення & 0,05 & $-0,7$ & $-1,2$ \\
Радість & 0,16 & $-0,4$ & 0,1 \\
Благополуччя & 0,07 & 0,0 & 0,24 \\
Свобода & 0,9 & $-0,11$ & 1,2 \\
\hline
\end{tabular}

Натомість, проаналізувавши показники за фактором «Слабкість» (Ф2), легко впевнитися, що розташування категорій у даному просторі та ті параметри, згідно 3 якими більшість показників мають негативне значення, свідчать про негативне ставлення пацієнтів з соматогенією до цілої низки як категорій саморегуляції, так і категорій психічного стану, що підтверджує їхню розчарованість і зневіреність у самому собі.

Що стосується фактору «Активність» (ФЗ), то єдиним позитивним показником тут виступає цінність «свобода», але, зваживши на всі інші індикатори семантичного простору, легко помітити, що у цьому семантичному просторі свобода виступає, можливо, омріяною, але безпідставною i нічим не забезпеченою цінністю.

Отже, в лікуванні соматогеній неможливо не враховувати власне індивідуально-психологічні, особистісні чинники, зокрема психосемантичну структуру власного «я» пацієнта. Очевидно, що саме психологічні ресури пацієнта, опредмечені у системі уявлень та оціночних суджень, відіграють стимулюючу або 
гальмуючу в подоланні труднощів. Сутність проблематики каузації найрізноманітніших хворобливих станів організму полягає у вивченні особливостей складних взаємодій патогенних i протективних внутрішніх i зовнішніх факторів. При цьому методологія психосемантичних досліджень в клініці захворювань різного спектру повинна спиратися на розуміння особливостей когнітивного, емоційного, поведінкового компонентів системи ставлень до хвороби; на знання психології здоров〉я і особливостей особистісних ресурсів людини, що страждає на те чи інше соматичне захворювання. Ці важливі нюанси розуміння співвідношення клінічних, психофізіологічних та власне суто психологічних механізмів впливу категоріальної структури свідомості на динаміку психічних станів пацієнтів з соматогенію і повинні враховуватися у виборі й структуруванні особистісно-орієнованої психотерапії.

\section{Висновки}

Основним методом цього дослідження, пов'язаного 3 прикладною психолінгвістикою й експериментальною психосемантикою була побудова суб'єктивних семантичних просторів - своєрідне моделювання категоріальних структур індивідуальної мовної свідомості особистості. З'ясовано, що психосемантичний простір вищезазначених пацієнтів відрізняється когнітивно-емоційною простотою, низькою розмірністю, суперечливістю та переважанням негативних конотацій.

Безперечно, з огляду на те, що як вибірка, так і нозологічний ряд захворювань не дають підстав стверджувати, що в роботі вдалося побудувати універсальний психосемантичний простір таких пацієнтів, все ж дане дослідження вказує на той факт, що навіть з'ясована психосемантична структура свідомості пацієнтів, що страждають на соматогенію, передбачає особливі зусилля клінічних психологів та психотерапевтів у наданні цілеспрямованої психологічної підтримки та допомоги таким людям. I основна місія допомоги при соматогеніях полягає у відновленні особистісного «Я» пацієнта. Зрозуміла й найближча перспектива таких досліджень. Це - розширення діапазону прикладної психолінгвістики й психосемантики у застосуванні іiі до більш різноманітного кола нозологій, оскільки саме образ ідеальної, референтної постаті, 
ідентифікація з якою виступає проміжним, але важливим моментом життєствердження особистості, є в сучасній психотерапії окремою, пов'язаною 3 прикладною психолінгвістикою, дослідницькою проблемою. Саме у розкритті механізмів вільного внутрішнього діалогу особистісного «Я» 3 різними іпостасями себе, у вивільненні свого субстракту суб'єктності криється неабиякий потенціал психологічної й психолінгвістичної науки в ii прикладному застосуванні задля здійснення місії подолання широкого коло особистісних проблем, породжених, зокрема, соматогеніями. I психосемантичні дослідження, які у багатовимірному просторі внутрішньої картини хвороби здатні виявити суто індивідуальні компоненти, i соціокультурні детермінанти, i больові, ресурсні чинники, i базисні конструкти, що складають мовно-образну орієнтувальну основу в осмисленні свого страждання та перспектив власного життя - покликані виконувати багатоцільову місію: i діагностичну, i психолінгвотерапевтичну, i смислотвірну. На наш погляд, за такими дослідженнями - майбутнє прикладних когнітивних досліджень.

\section{Література}

Артемьева Е.Ю., Мартынов Е.М. Вероятностные методы в психологи. Москва: Изд-во МГУ, 1975. 206 с.

Гончаров В.Е. Возможности использования данных клинических шкал при разграничении психических расстройств различного генеза. Журнал психиатрии и медицинской психологии. 2011. № 1(26). С. 38-41.

Коростий В.И. Непсихотические психические расстройства и психологические факторы, влияющие на физическое состояние, у пациентов молодого возраста с психосоматической патологией. Международный медицинский журнал. 2011а. Т. 17. № 3. С. 13-17.

Коростий В.И. Эмоциональные расстройства у пациентов молодого возраста с психосоматическими заболеваниями: клинико-психопатологическая структура и дифференцированная коррекция. Медицинская психология. 2011b. № 4. C. 37-40.

Кудінова О.І. Особливості порушень психічної сфери у хворих на ішемічну хворобу серця і соматоформну вегетативну дисфункцію серцево-судинної системи. Медищинская психология. 2011. № 3. С. 57-59.

Леонтьев А.А. Язык, речь, речевая деятельность. Москва: КомКнига, 2007. 216 с.

Максименко К. Роль этиологии в понимании психических нарушений, связанных с болезненными состояниями организма человека. Психогенеза особистості: норма $і$ девіація: матеріали наук.-практ. семінару з міжнарод. участю (Луцьк, 3 квітня 2014 р.) / голов. ред. Я. Гошовський. Луцьк, 2014. С. 131-139. 
Максименко К.С. Личностно-ориентированная терапия эмоциональных расстройств при соматогениях. Киев: Изд-ий Дом «Слово», 2015. 352 с.

Максименко К.С., Калмиков Г.В., Психолінгвістична концепція і модель мовленнєвого впливу О.О. Леонтьєва та її значення для актуалізації сучасних проблем спілкування. Psycholinguistics. Психолингвистика. Психолінгвістика. 2018. Вип. 24(1). С. 220-235. https://doi.org/10.31470/2309-1797-2018-24-1$227-251$

Максименко С.Д., Орап М.О. Психолінгвістичні предиктори здоров’я. Psycholinguistics. Психолингвистика. Психолінгвістика. 2018. Вип. 24(1). C. 252-260. https://doi.org/10.31470/2309-1797-2018-24-1-252-268

Маркова М.В., Кутова Н.В. Хронічний панкреатит - як модель соматичної хвороби 3 психотравматичними наслідками. Український вісник психоневрології. 2015. Т. 23. Вип. 2(83). С. 111-112.

Мелзак Р. Загадка боли. Москва: Медицина, 1981. 231с.

Михайлов Б.В. Романова І.В., Андрух Г.П. та ін. Принципи побудови підготовки фахівців для лікування хворих на соматичні та психічні розлади. Медицинская психология. 2011. № 4. С. 65-66.

Михальский А.И., Иванов В.К., Максютин М.А., Моргенштерн В. Оценка динамики заболеваемости ликвидаторов по результатам ежегодных обследований. Радиаџия и риск. 1996. № 8. С. 38-46.

Петренко В.Ф. Основы психосемантики. Санкт-Петербург: Питер, 2005. 480 с.

Прохоров А.О. Системный анализ психического состояния состояний. Психология состояний. Москва: ПЕР СЭ; Санкт-Петербург: Речь, 2004. С. 141-153.

Штрахова А.В. Психосемантика боли в структуре внутренней картины болезни у неврологических больных. Вестник ЮУрГУ. 2009. № 30. С. 76-82.

Щеглов Л.М. Психология соматического больного. Медицинская психология. 2006. № 3. C. 22-28.

The Emotional Impact of Spinal Cord Injury on the Family. (2012). Retrieved from http://www.spinal.co.uk/userfiles/pdf/factsheets/Free_to_download/emotional_ impact_of_SCI_on_family.pdf

Pagoto, S. (2011). Psychological Co-Morbidities of Physical Illness: A Behavioral Medicine Perspective. Springer, NY. https://doi.org/10.1007/978-1-4419-0029-6

Pervichko, E., Zinchenko, Y., \& Pak, L. (2016). Psychosemantics of Pain in Patients with Coronary Artery Disease. European Psychiatry, 33, 625-626. https://doi. org/10.1016/j.eurpsy.2016.01.1849

Tuval-Mashiach, R., Freedman, S., Bargai, N. et al. (2004). Coping with Trauma: Narrative and Cognitive Perspectives. Psychiatry, 67(3), 280-293. https://doi. org/10.1521/psyc.67.3.280.48977

Kreitler, S., \& Kreitler, H. (1985). The psychosemantic determinants of anxiety: A cognitive approach. In Ploeg van der H., R. Schwarzer \& C.D. Spielberger (Eds.), Advances in Text Anxiety Research. (Vol. 4), (pp. 117-135). Swets and Zeitlinger and Erlbaum, the Netherlands and Hillsdale, N.J.

\section{References}

Artemeva, E.Yu., \& Martynov, E.M. (1975). Veroyatnostnye metody $v$ psikhologii [Probabilistic methods in psychology]. Moscow: Izd-vo MGU [in Russian]. 
Goncharov, V.E. (2011). Vozmozhnosti ispolzovaniya dannyih klinicheskih shkal pri razgranichenii psihicheskih rasstroystv razlichnogo geneza [The possibilities of using the data of clinical scales in differentiation of the mental disorders of different genesis]. Zhurnal psihiatrii $i$ meditsinskoy psihologii - Journal of Psychiatry and Medical Psychology, 1(26), 38-41 [in Russian].

Korostiy, V.I. (2011). Nepsihoticheskie psihicheskie rasstroystva i psihologicheskie faktoryi, vliyayuschie na fizicheskoe sostoyanie, $\mathrm{u}$ patsientov molodogo vozrasta s psihosomaticheskoy patologiey [Non-psychotic mental disorders and psychological factors affecting the physical condition in young patients with psychosomatic pathology]. Mezhdunarodnyiy meditsinskiy zhurnal - International Medical Journal, 17(3), 13-17 [in Russian].

Korostiy, V.I. (2011). Emotsionalnyie rasstroystva u patsientov molodogo vozrasta s psihosomaticheskimi zabolevaniyami: kliniko-psihopatologicheskaya struktura i differentsirovannaya korrektsiya [Emotional disorders in young patients with psychosomatic diseases: clinical and psychopathological structure and differentiating correction]. Meditsinskaya psihologiya - Medical psychology, 4, 37-40 [in Russian].

Kudinova, O.I. (2011). Osoblivosti porushen psihIchnoyi sferi u hvorih na ishemIchnu hvorobu sertsya i somatoformnu vegetativnu disfunktsiyu sertsevo-sudinnoyi sistemi [Emotional disorders in young patients with psychosomatic diseases: clinical and psychopathological structure and differentiating correction]. Meditsinskaya psihologiya - Medical psychology, 3, 57-59 [in Ukrainian].

Leontev, A.A. (2007). Yazyik, rech, rechevaya deyatelnost [Language, speech, speech activity]. Moscow: KomKniga [in Russian].

Maksimenko, K.S. (2015). Lichnostno-orientirovannaya terapiya emotsionalnyih rasstroystv pri somatogeniyah [Person-oriented therapy of Emotional Disorders in Somatogens]. Kyiv: Izdatelskiy Dom «Slovo» [[in Russian].

Maksimenko, K.S. (2014). Rol etiologii v ponimanii psihicheskih narusheniy, svyazannyih s boleznennyimi sostoyaniyami cheloveka [The role of etiology in understanding the mental disorders associated with painful conditions of the human body]. In Ya. Goshovskiy (Eds.), Psihogeneza osobistosti: norma $i$ deviatsiya - Psychogenesis of personality: the norm and deviation: Proceedings from scientific-practical seminar on the international. Participation, (p. 220). Lutsk [in Ukrainian].

Maksymenko, K., \& Kalmykov, H. (2018). Psyxolingvistychna koncepciya i model movlennyevogo vplyvu O.O. Leontyeva ta yiyi znachennya dlya aktualizaciyi suchasnyx problem spilkuvannya [Psycholinguistic Concept and the Model of Speech Influence by A.A. Leontiev and Its Importance for Actualization of the Modern Communication Problems]. Psiholingvistika - Psycholinguistics, 24(1), 227-251. https://doi.org/10.31470/2309-1797-2018-24-1-227-251 [in Ukrainian].

Maksymenko, S., \& Orap, M. (2018). Psyxolingvistychni predyktory zdorovya [Psycholinguistic Predictors of Health]. Psiholingvistika - Psycholinguistics, 24(1), 252-268. https://doi.org/10.31470/2309-1797-2018-24-1-252-268 [in Ukrainian].

Markova, M.V., \& Kutova, N.V. (2015). Khronichnyi pankreatyt - yak model somatychnoi khvoroby z psykhotravmatychnymy naslidkamy [Chronic pancreatitis as a model of somatic illness with psychotraumatic consequences]. Ukrainskyi visnyk psykhonevrolohii - Ukrainian Herald of Psychoneurology, 23(2), Iss. 83, 111-112 [in Ukrainian]. 
Melzak, R. (1981). Zagadka boli [Riddle of pain]. Moscow: Medttstna [in Russian].

Mihaylov, B.V., Romanova, I.V., Andruh, G.P. et. al. (2011). Printsipi pobudovi pidgotovki fahivtsiv dlya likuvannya hvorih na somatichni ta psihichni rozladi [Principles of specialists' training construction for the treatment of patients with somatic and mental disorders]. Meditsinskaya psihologiya - Medical psychology, 4, 65-66 [in Ukrainian].

Mihalskiy, A.I., Ivanov, V.K., Maksyutin, M.A., \& Morgenshtern, V. (1996). Otsenka dinamiki zabolevaemosti likvidatorov po rezultatam ezhegodnyih obsledovaniy [Assessment of the dynamics of the morbidity of liquidators based on the results of annual surveys]. Radiatsiya i risk-Radiation and Risk, 8, 38-46 [in Russian].

Scheglov, L.M. (2006). Psihologiya somaticheskogo bolnogo [Psychology of the somatic patient]. Meditsinskaya psihologiya - Medical psychology, 3, 22-28 [in Russian].

Petrenko, V.F. (2005). Osnovyi psihosemantiki [Fundamentals of psychosemantics]. Saint Petersburg: Piter [in Russian].

Prohorov, A.O. (2004). Sistemnyiy analiz psihicheskogo sostoyaniya sostoyaniy [Systemic analysis of mental states]. Psihologiya sostoyaniy - Psychology of the states, (pp. 141-153). Moscow: PER SE; Saint Petersburg: Rech [in Russian].

Shtrahova, A.V. (2009). Psihosemantika boli v strukture vnutrenney kartinyi bolezni $\mathrm{u}$ nevrologicheskih bolnyih [Psychosemantics of pain in the structure of the internal picture of disease in the neurological patiens]. Vestnik Yuzhno-Uralskogo gosudarstvennogo universiteta - Bulletin of the South Ural State University, 30, 76-82 [in Russian].

The Emotional Impact of Spinal Cord Injury on the Family. (2012). Retrieved from http://www.spinal.co.uk/userfiles/pdf/factsheets/Free_to_download/emotional_ impact_of_SCI_on_family.pdf

Pagoto, S. (2011). Psychological Co-Morbidities of Physical Illness: A Behavioral Medicine Perspective. Springer, NY. https://doi.org/10.1007/978-1-4419-0029-6

Pervichko, E., Zinchenko, Y., \& Pak, L. (2016). Psychosemantics of Pain in Patients with Coronary Artery Disease. European Psychiatry, 33, 625-626. https://doi. org/10.1016/j.eurpsy.2016.01.1849

Tuval-Mashiach, R., Freedman, S., Bargai, N. et al. (2004). Coping with Trauma: Narrative and Cognitive Perspectives. Psychiatry, 67(3), 280-293. https://doi. org/10.1521/psyc.67.3.280.48977

Kreitler, S., \& Kreitler, H. (1985). The psychosemantic determinants of anxiety: A cognitive approach. In Ploeg van der H., R. Schwarzer \& C.D. Spielberger (Eds.), Advances in Text Anxiety Research. (Vol. 4), (pp. 117-135). Swets and Zeitlinger and Erlbaum, the Netherlands and Hillsdale, N.J.

\section{АНОТАЦІЯ}

у статmі наводяться результати дослідження суб'єктивного психосемантичного простору пацієнтів, які страждають на соматогенію. Побудова суб'єктивного семантичного простору принципово відрізняється від описових досліджень тим, що передбачає проведення експерименту, що моделює ті чи інші аспекти мовної або когнітивної діяльності і дозволяє здійснити реконструкцію системи значень. Йдеться про дослідження 
Psychosemantic Reconstruction of Health Concepts in Patients...

психосемантичної структури тих смислових структур свідомості, що створюють типову концептуальну систему саморегулячії, фрормуючи нормативну та фактичну суб'єктивну картину власних уявлень про здоров'я та психологічні причини його порушення.

На прикладі пацієнтів з хронічними гастроентерологічними та серцевосудинними захворюваннями автор методом семантичного диференціалу 4. Осгуда з наступною факторизацією даних встановив основні психосемантичні параметри свідомості таких пацієнтів, що дозволяє зрозуміти, яким чином люди з певною структурою свідомості потрапляють в число пацієнтів, які страждають на психогенію. Метод семантичного диреренціалу дозволяє оцінити суб'єктивний аспект значень, які пов'язані зі змістом, соціальними установками, стереотипами та іншими емоційно навантаженими, структурованими й малоусвідомленими формами узагальнення. Дослідження проходило у три етапи. На першому - застосовувався прийом асоціацій. На другому етапі було отримано масив даних, що представляли собою результат застосування методики семантичного диференціалу до опису зазначених категорій. Третій етап був спрямований на опрацювання отриманих фактологічних даних.

Через дослідження були отримані результати у вигляді трьох факторів. Головний фактор отримав назву «Оцінка». Другий (частковий) біполярний фактор увібрав в себе три шкали і отримав назву - антонім до класичної шкали Ч. Осгуда «Слабкість». Третій (частковий) уніполярний фрактор також містить три шкали. Він отримав назву «Активність».

Дослідження виявило низку спільних рис, що характеризують частковий психосемантичний простір таких пацієнтів. Було з'ясовано, що психосемантичні параметри психосемантичного простору пацієнтів відрізняються когнітивно-емочійною простотою, низькою розмірністю, суперечливістю та переважанням негативних конотацій.

Психосемантична структура свідомості пачієнтів,що страждають на психогенію, передбачає особливі зусилля клінічних психологів та психотерапевтів у наданні цілеспрямованої психологічної підтримки та допомоги таким людям.

Ключові слова: структура свідомості, психосемантичний простір, соматогенія, факторний аналіз,психологічна допомога.

\section{Максименко Ксения, Кудермина Елена. Психосемантическая реконструкция представлений о здоровье у пациентов с соматогенией}

\section{АННОТАЦИЯ}

В статье приводятся результаты исследования субъективного психосемантического пространства пациентов, страдающих на соматогению. Построение субъективного семантического пространства принципиально отличается от описанных исследований тем, что предусматривает 
проведение эксперимента, моделирующего те или иные аспекты языковой или когнитивной деятельности и позволяет осуществить реконструкцию системь значений. Речь идет об исследовании психосемантической структуры тех смысловых структур сознания, которые создают типичную концептуальную систему саморегуляции, формируя нормативную и фактическую субъективную картину собственных представлений о здоровье и психологчческие причины его нарушения.

Ha примере пациентов с хроническими гастроэнтерологическими и сердечно-сосудистыми заболеваниями авторами с помощью метода семантического дифреренциала Ч. Осгуда с последующей факторизацией данных установлены основные психосемантические параметры сознании таких пациентов, что позволяет понять, каким образом люди с определенной структурой сознания попадают в число пациентов, страдающих психогенией. Метод семантического диффреренциала позволяет оценить субъективный аспект значений, связанный с содержанием, социальными установками, стереотипами и другими эмоционально нагруженными, структурированными и малоосмысленными формами обобщения. Исследование проходило в три этапа. На первом - применялся прием ассоциаций. На втором этапе был получен массив данных, представляющих собой результат применения методики семантического дифреренциала к описанию указанных категорий. Третий этап был направлен на анализ полученных фактологических данных.

Через исследования были получены результаты в виде трех факторов. Главный фрактор получил название «Оценка». Второй (частичный) биполярный фактор вобрал в себя три шкалы и получил название "Антоним» к классической шкале Ч. Осгуда "Слабость». Третий (частичный) униполярный фрактор также содержит три шкалы. Он получил название "Активность».

Исследование выявило ряд общих черт, характеризующих частичный психосемантический пространство таких пациентов. Было выяснено, что психосемантические параметры психосемантического пространства пациентов отличаются когнитивно-эмоциональной простотой, низкой размерностью, противоречивостью и преобладанием негативных коннотаций.

Психосемантическая структура сознания пациентов, страдающих психогенией, предусматривает особые усилия клинических психологов и психотерапевтов в предоставлении целенаправленной психологчческой поддержки и помощи таким людям.

Ключевые слова: структура сознания, психосемантическое пространство, соматогения, факторный анализ, психологическая помощь. 